\title{
PENGELOLAAN ADMINISTRASI DALAM PENINGKATAN MUTU PENDIDIKAN
}

\author{
Nur Jamal \& Masykurotus Syarifah \\ STAI Nazhatut Thullab Sampang \\ Email: jamalnr73@yahoo.com
}

\begin{abstract}
Abstrak
Seringkali pengelolaan administrasi pendidikan masih dikesampingkan dalam peningkatan mutu pendidikan. Masih banyaknya lembaga pendidikan yang kurang memperhatikan terhadap pengelolaan administrasi. Hal ini menjadikan lembaga pendidikan kemudian seperti mobil yang dikendalikan tanpa adanya aturan dan tujuan yang pasti. Sudah seharusnya difahami bahwa salah satu aspek yang urgen untuk dilakukan dalam rangka peningkatan mutu pendidikan adalah adanya pengelolaan administrasi yang bagus baik untuk tenaga pendidik maupun tenaga kependidikan. Peningkatan kemampuan tersebut akan berakibat positif dan efektif dalam peningkatan kualitas lembaga pendidikan. Pengelolaan administrasi yang baik merupakan salah satu rangkaian dalam upaya peningkatan mutu pendidikan. Pembinaan dan pengembangan kemampuan profesional tenaga pendidik maupun kependidikan yang dilaksanakan secara bermutu melalui peningkatan adminstrasi pendidikan yang baik akan dapat meningkatkan kualitas lembaga pendidikan. Oleh karena itu, peningkatan mutu pendidikan salah satunya sangatlah tergantung pada pengelolaan administrasi pendidikan.
\end{abstract}

Kata Kunci: Pengelolaan Administrasi, Peningkatan mutu Pendidikan

\begin{abstract}
Often the management of education administration is still ruled out in improving the quality of education. There are still many educational institutions that pay less attention to administrative management. This makes later educational institutions like cars that are controlled without any definite rules and objectives. It should be understood that one of the urgent aspects to be carried out in order to improve the quality of education is good administrative management for both educators and education staff. This increase in capacity will have a positive and effective impact on improving the quality of educational institutions. Good administrative management is one of a series in efforts to improve the quality of education. The fostering and development of the professional abilities of educators and education staff carried out in a quality manner through improved education in good education will improve the quality of educational institutions. Therefore, improving the quality of education is very dependent on the management of educational administration.
\end{abstract}

Keywords: Administrative Management, Educational Quality Improvement 


\section{Pendahuluan}

Setiap satuan pendidikan dipimpin oleh seorang kepala satuan sebagai penanggung jawab pengelolaan pendidikan yang disebut Kepala sekolah. Pembangunan nasional akan dapat terwujud dengan adanya sumber daya manusia yang mampu bersaing dan berdaya guna. Hal ini akan terjadi jika kualitas pendidikan di Indonesia bermutu. Karena masa depan bangsa tentunya bisa diukur dari kualitas lembaga pendidikan yang mampu berdiri kokoh di zaman tekhnologi seperti sekarang ini. Tentunya tata kelola adminisrasi pendidikan yang akan menjadi sorotan pertama dalam mengukur tingkat kualitas suatu lembaga pendidikan. Peranan sumber daya manusia yang profesional dan potensial menjadi faktor penentu dalam mewujukan lembaga pendidikan yang administratif. Oleh karena itu upaya peningkatan mutu madrasah /sekolah merupakan titik sentral dan strategis dalam menciptakan pendidikan yang berkualitas, dinamis, mandiri, dan proaktif.

Paradigma baru mempercayai terhadap pengelolaan administrasi pendidikan untuk menjadi kewenangan penuh bagi setiap pimpunan lembaga pendidikan, mulai dari planning, organizing, aplication, controling, dan pengembangan lembaga pendidikan yang dipimpinya. Pimpnan lembaga pendidikan memliliki tugan dan responsibility yang tinggi. Tentunya hal ini menuntut kepekaan yang tinggi terhadap pimpinan lembaga pendidikan dengan berbagai konsekuensi yang harus diterima. Di samping itu, percepatan perkembangan ilmu pengetahuan, tekhnologi, dan seni yang merambah ke dunia pendidikan, sehingga tugas dan taggung jawab pimpinan lembaga pendidikan semakin kompleks.

Oleh karena itu kepala madrasah/sekolah sebagai pimpinan dalam pengelolaan administrasi pendidikan dituntut memiliki kesiapan mental dalam rangka memahami perubahan yang terjadi dengan segala konsekuensinya. Dengan berbekal kesiapan mental dalam bentuk kecerdasan emosional, kepala madrasah/sekolah akan bijak dalam memahami segala perubahan yang terjadi. Pengembangan sumber daya manusia Indonesia saat ini menjadi bagian integral dalam pembangungan bangsa, oleh karena itu kesiapan lembaga pendidikan dalam menyongsong era global yang ditandai dengan adanya desentralisasi pendidikan, dan otonomi pendidikan maka tidak boleh dikesampingkan dalam hal tata kelola bidang adiministrasi pendidikan.

Tata kelola bidang administrasi pendidikan harus dilaksanakan secara profesional baik oleh tenaga pendidik maupun tenaga kependidikan dan menjadi tugas dan tanggug jawab bersama dengan sinergitas yang tinggi dari semua stakeholder yang ada. Mengingat makin majunya ilmu pengetahuan dan makin berkembangnya tekhnologi yang semakin pesat menjadi tuntutan bagi lembaga pendidikan untuk tidak ketinggalan zaman.

\section{Pembahasan}

\section{Pengertian Pengelolaan Administrasi Pendidikan}

Dalam tatanan bahasa, Winarno mendefinisikan pengelolaan diambil dari akar kata mengelola. ${ }^{1}$ Dalam artian suatu aktifitas yang diakukan mulai dari tahapan pengumpulan data, planning, organizing, aplication, controlling, dan

\footnotetext{
${ }^{1}$ Anonim, Pengelolaan Pendidikan, (Jakarta: Rineka Cipta, 2005), 59.
} 
evaluation. Dapat diarikan bahwa proses yang dilakukan dalam rangka mencapai tujuan tertenntu dimana hasinya dievaluasi untuk mengasilkan sesuatu yang lebih maksimal lagi, maka hal ini yang disebut dengan pengelolaan. ${ }^{2}$

Pengelolaan sama halnya dengan istilah manajemen yang mengandung arti tata kelola. Nurhadi dalam bukunya adminstrasi pendidikan menyebutkan ada delapan tata kelola manajemen pendidikan. Diantaranya; administrasi organisasi, administrasi kepegawaian, administrasi kurikulum, administrasi kesiswaan, administrasi pembiayaan pendidikan, administrasi sarana dan prasarana, administrasi tata usaha, dan administrasi hubungan masyarakat. ${ }^{3}$

Pengelolaan pendidikan sebagai sebuah institusional atau sistem satuan pendidikan merupakan suatu proses untuk merumuskan kebijakan dan tujuan organisasi. ${ }^{4}$

Ada enam bagian tata kelola administrasi pendidikan yaitu; ${ }^{5}$

a. Kurikulum; Kurikulum merupakan segala bentuk kegiatan yang mendukung terjadinya proses pembelajaran secara komprehensif yang terencana dan terorganisir.

b. Peserta didik, peserta didik adalah subjek pendidikan yang merupakan pelaku pendidikan yang melaksanakan tugas pembelajaran sesuai dengan mekanisme kegiatan belajar yang telah direncanakan.

c. Tenaga pedidik atau guru dan tenaga kependidikan.

d. Dalam melaksanakan tata kelola administrasi pendidikan mebutuhkan sektor pendanaan baik untuk pengadaan, pemeliharaan, ataupun pembinaan

e. Dalam melaksanakan program kegiatan pembelajaran membutuhkan sarana dan prasarana baik berupa gedung, alat pendidikan konvensional ataupun alat pendidikan tekhnologi, dan lainnya yang nantinya akan menopang jalannya proses pembelajaran.

f. Lingkungan merupakan salah satu komponen yang tidak terpisahkan, mulai dari keadaan sosial budaya, ekonomi, ideologi, tokoh masyarakat, dan warga masyarakat pada umumnya.

Secara keseluruhan hendaknya tata kelola dilakukan semaksimal mungkin demi terwujudnya tujuan organisasi dalam hal ini satuan lembaga pendidikan. Baik pengelolaan kurikulum atau pengelolaan program kegiatan belajar, kesiswaan, kepegawaian, sarana dan prasarana, keuangan, dan pengelolaan hubungan dengan masyarakat.

Manajemen pengelolaan administrasi pendidikan dapat ditinjau dari tiga aspek, yaitu aspek kelembagaan, layanan pembelajaran, yang diorientasikan kepada learning organization, dan aspek kompetensi siswa.

\section{Manajemen kelembagaan}

Sekolah sebagai tempat pembelajaran membutuhkan manajemen kelembagaaan yang harus diaplikasikan. Sasaran manajemen kelembagaan adalah segala bentuk tata kelola yang harus dilakukan muai dari tata kelola bidang

\footnotetext{
${ }^{2}$ Hasan Alwi, Kamus Besar Bahasa Indonesia, (Jakarta: Balai Pustaka, 2005), 534.

${ }^{3}$ Nurhadi, Administrasi Pendidikan, (Jakarta: Balai Pustaka, 2009), 5.

${ }^{4}$ Hasan, Kamus Besar, 534.

${ }^{5}$ Anonim, Pengelolaan Pendidikan, 65.
} 
kurikulum, bidang kesiswaan, bidang ketenagaan, bidang sarana dan prasarana, bidang pendanaan dan kerjasama dengan masyarakat.

a. Tata kelola bidang kesiswaan

Siswa akan belajar dengan efektif bila kurikulum dikembangkan secara gradual (bertahap) berdasarkan kebutuhan dan kepentingan siswa. Seharusnya kurikulum sekolah disesuaikan dengan kebutuhan peserta didik. Sehingga jika terjadi persoalan pendidikan yang melibatkan salah satu peserta didik tidak akan memunculkan kecemburuan sosial yang natinya akan berdampak terhadap keberlangsungan proses pembelajaran. ${ }^{6}$

Dalam melaksanakan rekrutmen peserta didik hendaknya dilakukan secara fair, terbuka, dan prosedural. Disinilah peranan manajemen kesiswaan diterapkan. Mulai dari adanya seleksi penerimaan peserta didik yang adil dan jujur bail melalui tes tulis ataupun tes lisan dan hal lainnya. Berikut ketika munculnya persoalan yang melibatkan peserta didik, hal ini membutuhkan adanya bimbingan secara khusus sehingga menemukan solusi terbaik.

Manajemen sekolah yang efektif bagi bidang kesiswaan diarahkan untuk menumbuhkembangkan kecerdasan, minat dan bakat, meningkatkan keimanan dan ketaqwaan, dan untuk menegakkan disiplin siswa. Beberapa hal yang menandakan adanya manajemen sekolah yang baik adalah dengan adanya berbagai prestasi yang diperoleh oleh peserta didik baik prestasi akademik maupun non akademik, adanya kedisiplinan yang merata bagi peserta didik, aktif dalam mengikuti kegiatan sekolah, dan minimnya angka peserta didik yang drop out.

b. Tata kelola bidang ketenagaan

Dalam menata bidang ketenagaan hendaknya dimulai sejak adanya rekrutmen tenaga pendidik dan tenaga kependidikan. Hal yang perlu diperhatikan dalam menyeleksi calon tenaga pendidik dan tenaga kependidikan adalah bidang keahlian yang dimiliki, keluwesan dalam bersosial baik dilingkungan sekolah khususnya ataupun masyarakat pada umumnya.tata kelola dalam bidang ketenagaan tidak hanya berhenti pada aspek keahlian saja, namun lebih dari itu pada peningkatan kualitas sumber daya manusia pada masing-masing tenaga pendidik dan tenaga kependidikan.

Profesionalisasi seorang pendidik dalam melaksanakan tugas pembelajaran sangat urgen untuk dilaksanakan. Begitu juga pada aspek kecerdasan emosionalnya betul-betul harus diaplkasikan dalam bentuk nyata. Baik terhadap peserta didik ataupun lainnya.

c. Tata kelola bidang kurikulum

Adanya pengorganisasian kurikulum yang dapat berupa analisis kurikulum yang dijabarkan ke dalam komponen-komponen program pengelolaan pendidikan. Adanya pembaharuan kurikulum yang terjadi di Indonesia menuntut tehadap kesanggupan setiap lembaga pendidikan dalam mengembangkan diri, peningkatan dan penyesuaian terhadap munculnya berbagai inovasi. Lembaga pendidikan harus adaptable dengan kondisi kekinian. Pemantapan dalam bidang

\footnotetext{
${ }^{6}$ Direktorat Jenderal Kelembagaan Agama Islam, Desain Pengembangan Madrasah, (Jakarta : Departemen Agama RI, 2004), 28-29.
} 
penyusunan silabus misalnya perlu adanya pengkajian ulang sehingga sesuai dengan kebutuhhan zaman dan harus up to date. ${ }^{7}$

Lembaga pendidikan harus mampu mengantarkan peserta didik yang potensial, memiliki keserdasan intelektual, emosional, dan spiritual yang tinggi. Lembaga pendidikan harus mempersiapkan peserta didik yang memiliki berbagai keterampilan yang akan menopang kehidupan perserta di masa yang akan datang., antara lain berupa keterampilan motorik/manual, kemampuan intelektual, sosial dan emosional.

Dalam implementasinya pengembangan life skills meliputi ke trampilan hidup yang relevan yang dipelajari madrasah setelah menyelesaikan satuan program belajar tertentu, bahan belajar yang harus dipelajari agar ketrampilan hidup tersebut dikuasai siswa agar benar-benar dikuasai siswa yang mempelajarinya, sarana dan prasarana pendukung kepemilikan ketrampilan yang diinginkan, dan indikator keberhasilan peserta didik yang mengikutinya.

d. Tata kelola bidang sarana prasarana

Tata kelola dalam bidang sarana dan prasarana merupakan hal yang sangat urgen dalam menopang terlaksananya proses pembelajaran yang efektif. tata sarana dan prasarana harus dilakukan secara maksimal sehingga nantinya akan menciptakan suasan yang aman, tertib, indah, dan nyaman. Adanya ketersedian sarana dan prasarana yang memadai juga harus dimbangi dengan tingkat pemeliharan yang juga harus maksimal.

e. Tata kelola bidang keuangan

Penataan keuangan lembaga pendidikan hendaknya dilakukan secara profesional. Dalam artian nilai-nilai keterbukaan dalam pengelolaan keuangan harus dilakukan. Pemasukan dan dan pengeluaran harus dipertanggungjaabkan secara utuh. Dalam mengelola dana yang diperoleh dari berbagai sumber maka pihak sekolah harus benar-benar bisa mengelola keuangan secara rinci cermat, dan teliti. Dalam hal ini dikarenakan banyaknya kebutuhan yang harus dipenuhi dalam mengembangkan sekolah.

Sebelum tahun anggaran berjalan, Kepala lembaga pendidikan harus menyusun Rencana Anggaran Pendapatan Dan Belanja Sekolah (RAPBS) dalam jangka waktu satu tahun ke depan. Rencana anggaran pendidikan tersebut berisi seluruh rencana pendapatan dan pengeluaran anggaran madrasah dan disusun oleh kepala madrasah bekerjasama dengan para guru, staff dan komite madrasah.

f. Tata kelola bidang hubungan masyarakat

Lembaga pendidikan meupakan bagian dari masyarakata. Untuk itu tidak bisa dipungkiri adanya jalinan kerjasama antara pihak sekolah dan masyarakat. Stake holder dari lembaga pendidikan di dalamnya juga meliputi masyarakat. Artinya masyarakat merupakan raw input dan sekaligus yang menunggu lulusan dari sebuah lembaga pendidikan. Manajemen kemitraan msekolah dengan masyarakat harus bisa mengakomodasi kepentingan-kepentingan sekolah kepada masyarakat dan begitu juga sebaliknya. Realisasinya dapat berupa terwujudnya program kemitraan dalam dewan sekolah/komite sekolah dan adanya partisipasi masyarakat dalam pengelolaan sekolah.

\section{Manajemen Layanan Pembelajaran}

\footnotetext{
${ }^{7}$ Hendyat Soetopo \& Wasty Soemanto, Pembinaan dan Pengembangan Kurikulum Sebagai Subtansi Problem Administrasi Pendidikan, (Jakarta : Bumi Aksara, 1993), 45.
} 
Layanan pembelajaran merupakan aspek utama organisasi dalam lembaga pendidikan. Lembaga pendidikan yang efektif senantiasa dapat menggali informasi dan dapat menyesuaikan diri terhadap perkembangan lingkungan yang kompleks dan dan penuh ketidakpastian. Layanan pembelajaran merupakan urusan utama madrasah yang menjadi patokan, terjadi atau tidaknya perubahan kemampuan siswa sebagai representasi dari upaya-upaya yang dilakukan guru dan manajemen sekolah. Oleh karena itu, layanan pembelajaran sekolah efektif ditujukan pada penciptaan seolah sebagai pengelola pembelajar (learning organization).

Pengelolaan pendidikan memberikan fasilitas belajar bagi anggotaanggotanya dan melakukan perubahan-perubahan secara terus menerus sebagai respon terhadap kebutuhan, harapan dan aspirasi dari orang-orang, baik yang baik secara interen maupun eksteren yang selalu mengalami perubahan.

Pengelolaan pendidikan yang efektif karena misinya selaras dengan misi madrasah efektif, yaitu terjadinya belajar secara kontinu dan selalu mengedepankan keterlibatan seluruh personel untuk belajar dalam berbagai tingkat dengan karakteristik diantaranya :

a. Tatanan, prosedur, dan aturan main dalam sebuah organisasi pendidikan harusmenjadi budaya (cultur akademik) yang harus diikuti semua pihak sehinnga dapat memeberikan motivasi pembelajaran, hal ini ditandai dengan munculnya;

1) Keterbukaan terhadap pengalaman;

2) Tidak menghindar dari kesulitan;

3) Adanya evaluasi terhadap berbagai kendala yang dihadapi untuk pengembangan selanjutnya.

b. Strategi organisasi menyatakan bahwa belajar merupakan sumber keunggulan strategi yang mantap (sustainable strategic advantage ).

c. Susunan organisasi yang fleksibel harus dimiliki oleh lembaga pendidikan.

d. Sistem informasi dalam organisasi pembelajar sangat akurat, tepat waktu, tersedia untuk siapapun yang membutuhkannya dan dalam bentuk yang mudah untuk dipergunakan.

e. Kepala lembaga pendidikan harus dipimpin oleh seorang yang mumpuni. ${ }^{8}$

\section{Manajemen Kompetensi Siswa}

Kompetensi siswa adalah kemampuan siswa yang dihasilkan selama dia mengikuti pembelajaran, artinya seberapa jauh siswa menyerap materi yang disampaikan guru, sejauh mana tujuan yang telah ditetapkan guru dapat dikuasai siswa, dan seberapa baik siswa mengikuti aturan-aturan yang telah ditetapkan, berinteraksi dengan dengan lingkungan sosialnya, dan kinerja yang ditunjukkannya dalam memecahkan masalah-masalah belajar dari kehidupan. ${ }^{9}$

Kompetensi pengetahuan dan ketrampilan adalah kompetensi yang mudah dinilai, diberikan, dilatihkan, diajarkan, dialami, dan dikembangkan karena merupakan kompetensi yang berada di permukaan yang cenderung dapat di lihat. Sumber dari kepribadian yang tidak mudah untuk dinilai dan dikembangkan melipti pengenalan terhadap diri, karakter, dan motivai yang bersifat lebih tersembunyi.

\footnotetext{
${ }^{8}$ Aan Komariah, Visionary Leadership Menuju Sekolah Efektif, (Jakarta: Bumi Aksara, 2005), 65.

${ }^{9}$ Sardiman, Interaksi dan Motivasi Belajar Mengajar. (Jakarta : Raja Grafindo, 2003), 11.
} 
Kompetensi harus dimiliki oleh siswa yaitu selain dapat digunakan untuk menembus seleksi masuk perguruan tinggi favorit, yang terkesan sebagai kompetensi akademik, juga untuk melanjutkan kehidupannya di masyarakat, artinya selain kompetensi untuk dapat bergaul dan hidup bersama di tengahtengah masyarakat, siswa juga harus memiliki kemampuan menghasilkan materi dari sejumlah keahliannya. Oleh karena itu, mereka harus dibekali dengan kemampuan life skills (kecakapan hidup).

Kemampuan life skills lebih luas dari keterampilan untuk hanya sekedar mencari penghasilan. Artinya, kecakapan hidup ini mencakup kemampuan individu atau seseorang untuk menyelesaikan berbagai persoalan kehidupannya yang bersifat praktik sosial maupun individual.

Departemen Pendidikan Nasional mengategorikan kecakapan hidup dalam lima pilar, yaitu: ${ }^{10}$

a. kecakapan mengenal diri ( self perseption), yang juga sering disebut

kemampuan yang dimiliki secara pribadi (personal skills );

b. kecakapan berpikir otentik ( thinking skills);

c. kecakapan sosial (social skills);

d. kecakapan akademik ( akademic skills);

e. kecakapan vokasional/khusus (vocational skills);

Lima pilar tersebut dikategorikan lagi menjadi dua, yaitu general life skills, yaitu kecakapan mengenal diri, berpikir rasional, dan kecakapan sosial. Sedangkan kecakapan akademik dan vokasional dikategorikan sebagai spesific life skills.

Penggunaan serta pemanfaatan secara efektif dan efisien terhadap semua unsur yang dilakukan secara terorganisir, terkoordiner, dan terintegrasi akan mampu mamaksimalkan bidang garapan administrasi sekolah dalam rangka mencapai tujuan utama yakni pendewasaan peserta didik.

Administrasi pendidikan merupakan rangkaian kegiatan oleh sekelompok manusia yang terlibat dalam proses pendidikan yang dilaksanakan berdasarkan tim work yang sudah dibentuk dengan tugas dan tanggung jawab masing-masing namun tidak melupakan yang namanya collective collegial. Artinya masing-masing memiliki peran dan fungsi namun tetap bekerja sama dan sama kerja.

Memaknai kalimat di atas, mengandung pengertian bahwa:

a. Administrasi merupakan wujud usaha manusia

b. Wujud usaha tersebut merupakan tata kelola pendidikan yang bersifat dinamis

c. Tata kelola tersebut dilakukan oleh sekelompok manusia yang terorganisir.

d. Proses itu dilakukan dalam rangka mencapai suatu tujuan yang telah ditetapkan sebelumnya.

e. Tata kelola pendidikan itu dilakukan agar mendapatkan tujuan yang sudah ditetapkan secara maksimal. ${ }^{11}$

\section{Fungsi Tata Kelola Administrasi Pendidikan}

Setiap proses pasti didalamnya ada usaha yang harus dilakukan. Begitu juga dalan tata kelola pendidikan. Mulai dari perencanaan, pelaksanaan, evaluasi dan

\footnotetext{
${ }^{10}$ Ibid, 15.

${ }^{11}$ Sofyan Tsauri, Administrasi dan Supervisi Pendidikan, (Jember: Society Studies, 2007), 2.
} 
penilaian semuanya membutuhkan apa yang disebut dengan proses. Tata kelola pendidikan dapat berjalan secara efektif dan efien jika dilakukan dengan usaha yang maksimal dan tdak setengah-setengah. Ada 8 ranah garapan tata kelola administrasi pendidikan yang asatu sama lainnya memiliki hubungan yang sangat erat dan tidak terpisahkan, satu sama sama lain saling menopang, diantaranya: perencanaan, pengorganisasian, koordinasi, komunikasi, supervisi, pendanaan dan evaluasi. Secara lebih jelas 8 garapan tersebut akan dijelaskan berikut ini:

a. Perencanaan (Planning)

Perencanaan merupakan merupakan pekerjaan awal pada setiap usaha yang harus dilakukan. Sehingga peranan perencanaan menjadi salah satu kunci suksenya sebuah usaha, begitu juga dalan tata kelola administrasi pendidikan. Tanpa adanya perencanaan, maka pelaksanaan suatu usaha tidak akan beraturan yang nantinya akan dihadapkan dengan berbagai persoalan yang sulit untuk diselesaikan. Perencanaan merupakan proses awal dari suatu usaha. Di dalam setiap perencanaan ada dua faktor yang harus diperhatikan, yaitu faktor tujuan dan faktor sarana, baik sarana personel maupun material.

Adapun tahapan-tahapan dalam proses perencanaan atara lain:

1. Merumuskan sesuatu yang ingin dicapai.

2. Mendeteksi segala bentuk persoalan yang akan muncul dalam menjalankan tanggung jawab.

3. Mencari informasi-informasi terkait dengan bidang garapan.

4. Melakukan penjadwalan dari tahapan-tahapan yang akan dilakukan.

5. Mencari solusi untuk pemecahan persoalan.

Merencanakan juga memiliki arti memikirkan untuk melakukan sebuah peroses/usaha secara efektif dan efisien baik terhadap tenaga, dana dan waktu, juga dalam rangkan meminimalisis kesalahan-kesalahan yang mungkin terjadi dan meniadakan adanya double job dan monopoli tugas sehingga dapat menghambat proses penyelesaian. Dalam hal ini perencanaan merupakan suatu proses memikirkan dan menentukan berbagai tugas dan tanggung jawab untuk mencapai tujuan pendidikan yang diinginkan. Adapu tahapan yang harus dilakukan adalah;

1. Pengorganisasian (Organizing)

Dalam sebuah organisasi semua unsur yang ada harus saling bekerja sama dan sama kerja guna mencapai tujuan organisasi yang diinginkan. Adanya kesatuan usaha yang diwujudkan oleh semua unsur inilah yang disebut dengan organizing. Namun demikian dalam kesatuan kerja ini memiliki perbedaan tugas yang disesuaikan dengan kemampuan dan kapasitas yang dimiliki oleh masing-masing personil dalam sebuah organisasi. Hal inilah yang disebut dengan job discribtion.

Lembaga pendidikan merupakan sebuah organisasi yang di dalamnya terdiri dari para personil yang menjadi bagian penting dalam melakukan tata kelola administrasi pendidikan. Kepala sekolah yang merupakan seorang pemimpin harus mumpuni di bidang administrasi pendidikan sehingga dapat menjalankan roda organisasi di lembaga pendidikan yang ia pimpin. Begitu juga semua unsur atau personil lainya juga harus memililiki kemampuan di bidang tata kelola administrasi pendidikan. Tentunya masing-masing personil memiliki tugas dan tanggung jawab yang berbeda yang membutuhkan kecakapan dan keterampilan sesuai tugas yang diamanahkan. Dengan adanya tugas dan tanggung jawab yang berbeda inilah menuntut semua unsur/personil bisa bekerja sama guna mencapai tujuan organisasi. 
Yang perlu diperhatikan dalam pengorganisasian antara lain ialah bahwa pembagian tugas, wewenang dan tanggung jawab hendaknya disesuaikan dengan pengalaman,bakat, minat, pengetahuan dan kepribadian masing-masing orang yang diperlukan dalam menjalankan tugas-tugas tersebut.

2. Pengkoordinasian (Coordinating)

Dalam menjalankan tata kelola administrasi pendidikan pelu adanya hubungan yang sehat antar pengelola pendidikan, baik itu tenaga pendidik ataupun tenaga kependidikan. Masing-masing pengelola dengan beban tugas yang berbeda diharapkan mampu bekerja secara maksimal dan ditopang dengan adanya koordinasi antar pengelola yang dipimpin oleh kepala lembaga pendidikan. Adanya tugas dan kewajiban yang berbeda jangan sampai menimbulkan persaingan yang nantinya akan memuncukan persaingan yang tidaksehat antar pengelola lembaga pendidikan. Dengan adanya koordinasi yang baik, semua bagian dan personel dapat bekerja sama menuju ke satu arah tujuan yang telah ditetapkan.

Pengkoordinasian diartikan sebagai usaha untuk menyatu padukan kegiatan dari berbagai individu agar kegiatan mereka berjalan selaras dengan anggota dalam usaha mencapai tujuan. Usaha pengkoordinasian dapat dilakukan melalui berbagai cara, seperti: (a) melaksanakan penjelasan singkat (briefing); (b) mengadakan rapat kerja; (c) memberikan unjuk pelaksanaan dan petunjuk teknis, dan (d) memberikan balikan tentang hasil sutu kegiatan. ${ }^{12}$

Dengan demikian ,koordinasi sebagai salah satu fungsi administrasi pendidikan dapat disimpulkan sebagi berikut : "koordinasi adalah aktivitas membawa orangorang, material, pikiran-pkiran, teknikk-teknik dan tujuan-tujuan kedalam hubungan yang harmonis dan produktif dalam mencapai suatu tujuan".

3. Komunikasi

Manusia disebut dengan makhluk sosial karena manusia tidak bisa hidup sendirian. Manusia membutuhkan orang lain sebagai teman untuk berbicara, bertukar fikiran, mencari solusi, atau hanya sekedar teman curhat. Begitu juga dalam melakukan tata kelola administrasi dalam sebuah lembaga pendidikan. Kominikasi sendiri bisa secara verbal dan juga non verbal.

Dalam melaksanakan tata kelola administrasi pendidikan sebgai wujud dari koordinasi maka masing-masing personil harus bisa saling memberkan masukan satu sama lain dengan komunikasi yang baik. Tanpa adanya komunikasi yang baik maka sudah barang tentu koordinasi tidak akan berjalan dengan baik pula, hal ini kemudian akan berimbas pada kegagalan terhadap tata kelola sebuah lembaga pendidikan karena akan berjalan pincang.

Komunikasi secara lisan pada umumnya lebih mendatangkan hasil dan pengertian yang jelas dari pada secara tertulis. Demikian pula komunikasi yang dilakukan secara informal dan secara formal mendatangkan hasil yang berbeda pengaruh dan kejelasannya.

Komunikasi dapat dilakukan secara bebas ataupun terbatas. Bebas dalam ariandapat melakukan komunikasi dengan setiap pengelola tanpa adanya batasanbatasan yang konkrit. Sedangkan komunikasi terbatas setiap pengelola organisasi hanya dapat melakukan komunikasi dengan batasan-batasan yang sudah ditentukan.

\footnotetext{
${ }^{12}$ Soetjipto dan Kosasi, Profesi Keguruan, (Jakarta: Rineka Cipta, 2008), 137.
} 
Dengan demikian, komunikasi dalam sebuah organisasi termasuk di dalamnya lembaga pendidikan merupakan sebuah proses dalam menyatukan niat dan kinerja untuk mencapai tujuan organisasi.

\section{Supervisi}

Adanya tugas dan tanggung jawab dari masing-masing pengelola administrasi pendidikan menuntut adanya controlling dari pimpinan lembaga pendidikan.dalam melaksanakan tugas dan fungsi masing-masing ada kalanya dapat dilaksanakan dengan baik sehingga mendapatkan hasil yang maksimal, namun demikian tidak menutup kemungkinan adanya personil yang melaksanakan tugas dan fungsinya hanya sebatas formalitas saja tanpa diringi dengan niat yang tulus untuk mencapai tujuan organisasi. Hal inilah yang menuntut setiap proses pelaksanan tugas dan fungsi masing-masing pengelola administrais pendidikan perlu diadakan supervisi.

Supervisi sebagai salah satu bagian dari fungsi administrasi menjadi urgen untuk dilaksanakan dalam rangka menentukan alur sesuai jobdis yang sudah ditentukan pada setiap pengelola administrasi pendidikan.

5. Kepegawaian (Staffing)

Dari uraian terdahulu seringkali disebutkan adanya pengelola/personel di lembaga pendidikan, baik itu tenaga pendidik maupun tenaga kependidikan. Inilah yang dimaksud dengan kepegawaian. Penekanannya lebih pada sosok manusia yang menjadi bagian dari lembaga pendidikan.

Proses yang dilakukan dalam kepegawaian meliputi; pemilihan personel, penempatan posisi disesuaikan dengan bidang keahlian yang dimiliki, adanya bimbingan yang harus dilakukan kepada masing-masing pesonel. Kepegawaian merupakan salah satu penentu tercapainya tujuan organisasi. Karena jika kemampuan/keahlian setiap personel sesuai dengan tugasnya maka jobdisc dari masing-masing personel dapat dilaksanakan dengan maksimal.

6. Pendanaan

Dalam menjalankan roda organisasi pasti membutuhkan yang namanya pendanaan. Aspek pendanaan merupakan hal yang sangat urgen dalam memenuhi kebutuhan-kebutuhan organisasi baik yang sifatnya materiil maupun non materiil. Logikanya seperti halnya kendaraan yang dijalankan oleh seorang sopir dengan membawa penumpang, tentunya kendaraan tersebut tidak mungkin bisa dijalankan tanpa adanya bensin.

Pendanaan seharusnya sudah dianggarkan dari awal sebelum pelaksanaan program-program yang direncanakan. Dengan demikian dibutuhkan seorang pengelola keuangan yang mahir dan mampu memanaj keuangan dalam sebuah organisasi.

Berangkat dari pentingnya pendanaan di atas, maka ada beberapa hal yang harus diperhatikan, diantaranya; ${ }^{13}$
a. Anggaran pendanaan yang dibutuhkan.
b. Langkah-langkah untuk mengimpun dana, dari sektor mana saja dana bisa terkumpul.
c. Untuk apa dana dikeluarkan.
d. Personel yang memanaj keuangan.
e. Adanya pembukuan dan pertanggungjawaban yang jelas.

\footnotetext{
${ }^{13}$ Sutjipto dan Basori Mukti, Administrasi Pendidikan, (Jakarta: Depdikbud Dirjen Dikti,1993), 33.
} 


\section{f. Langkah-langkah controlling yang harus dilakukan.}

\section{Penilaian (Evaluating)}

Setiap menjalankan roda organisasi harus diimbangi dengan adanya evaluasi baik oleh pimpinan lembaga pendidikan ataupun konsultan yang sudah ditunjuk oleh lembaga. Evaluasi harus dilakukan secara serius dan mendetail. Mulai dari planning sampai pada aplikasi. Dengan dilakukannya evaluasi maka nantinya akan ditemukan hal-hal yang mendukung dan menghambat program-program organisasi.

Evaluasi menjadi bagian dari fungsi administrasi pendidikan dalam rangka menggali informasi keterlaksanaan program yang telah disepakati untuk mencapai tujuan pendidikan. Evaluasi dilakukan kepada semua stake holder mulai dari unsur pimpinan sampai pada bidang-bidang yang memiliki amanah dan tanggung jawab masing-masing.

Dengan adanya evaluasi terhadap keseluruhan unsur-unsur organisasi maka dapat dikettahui adanya kendala-kendala yang menghambat jalannya laju organisasi. Dengan mengetahui kendala-kendala tersebut maka nantinya akan dapat mencarikan solusi/alternatif untuk meminimalisir hambatan-hambatan pada masa yang akan datang. ${ }^{14}$

Maksud dan tujuan dari evaluasi sebagai fungsi administrasi pendidikan yaitu;

a. Mengetahui hasil dari kinerja organisasi di lembaga pendidikan.

b. Mengetahui dan memahami bagaimana kinerja masing-masing personel.

c. Mengetahui hambatan-hambatan yang dihadapi pada satu periode sehingga tidak lagi terjadi pada periode berikutnya.

d. Menanamkan semanga kerja bagi para personel demi mewujudkan cita-cia organisasi. $^{15}$

Hal lain yang harus difahami dari fungsi-fungsi pokok yang telah dibicarakan di atas bahwa dari masing-masing fungsi tidak berdiri sendiri-sendiri, namun seperti rantai dimana ada kerikatan diantara yang satu dengan yang lainnya. Ketika salah satu fungsi tidak berjalan sebagaimana fungsinya maka tentunya akan berpengaruh tterhadap fungsiyang lain. Begitu juga sebaliknya.

\section{Tujuan Administrasi Pendidikan}

Menurut Sergiovanni dan carver dalam buku administrasi pendidikan dikatakan bahwa tujuan tata kelola administrasi adalah dalam rangka untnuk mennggapai citacita pendidikan. Artinya bahwa administrasi pendidikan memiliki peran sentral sebagai wujud usaha dalam mencapai tujuan lembaga pendidikan. Dikatakan bahwa ada empat tujuan administrasi, diantaranya; ${ }^{16}$

a. Efektifitas kinerja guna mendapatkan out put yang berhasil guna dan berdaya guna.

b. Efesiensi dalam bekerja

c. Adaptasi (adaptivenes)

d. Kepuasan hasil kerja

Beberapa tujuan di atas merupakan wujud usaha dalam mengejar produktifitas kinerja guna mendapatkan lulusan yang kreatif dan inovatif. Lembaga pendidikan dituntut untuk selalu membangun kinerja yang maksimal dari semua pengelola

\footnotetext{
${ }^{14}$ Purwanto, Administrasi Pendidikan, 15.

${ }^{15}$ Soetjipto, Profesi Keguruan, 138.

${ }^{16}$ Burhanuddin, Administrasi Pendidikan, (Bandung: Pustaka Setia, 2005), 67.
} 
embaga pendidikan. Hal ini akan terjadi jika semua personel tersebut mampu melaksanakan tugas sesuai dengan aturan main yag sudah disepakati bersama.

Menghadapi era 4.0 seperti sekarang ini menuntut semua lembaga penndidikan untuk mulai berbenah, tidak hanya diam ditempat. Namun harus menjadi lembaga pendidikan yang dapat menghasilkan peserta didik yang produktif, kreatif dan mampu menghadapi tantangan global.

\section{Prinsip-prinsip Administrasi Pendidikan}

Secara etimologi prinsip memiliki arti suatu pegangan yang disepakati semua fihak guna mencapai tujuan organisasi. Adapun prinsip-prinsip administrasi pendidikan dapat dirinci sebagai berikut:

a. Administrasi pendidikan dilaksanakan oleh dua orang atau lebih yang berada dalam sebuah organisasi pendidikan.

b. Masing masing personel memiliki tugas dan tanggung jawab masing-masing.

c. Pada setiap tugas dan taggung jawab yang dijalankan memiliki keterikatan antara satu san lainnya yang diatur secara rinci.

d. Memiliki sarana dan prasarana yang memadai sesuai dengan kebutuhan organisasi.

e. Adanya sistem kerja sama dan sama kerja antar personel. ${ }^{17}$

Prinsip-prinsip administrasi yang menyinggung organisasi, diantaranya adalah :

a. Memiliki tujuan organisasi yang jelas danspesifik.

b. Masing-masing personel memiliki tanggung jawab penuh terhadap tugas masingmasing.

c. Setiap personel mampu bekerjasama dengan lainnya dalam menjalankan tugastugas organisasi.

d. Ada garis komando yang jelas dan terarah.

e. Adanya koordinasi antara yang satu dengan lainnya dalam menjalankan peran dan fungsi masing-masing personel.

f. Kejelasan dalam pembagian tugas menjadi unsur penting dalam tata kelola pendidikan. Hal ini harus disesuaikan dengan kapasitas bidang keahlian yang dimiliki masing-masing personel. ${ }^{18}$

\section{Kesimpulan}

Dari paparan tersebut di atas, maka konklusi yang dapat diambil adalah bahwa pengelolaan administrasi pendidikan di lembaga pendidikan sangatlah penting, karena dengan pengelolaan yang baik dalam proses pembelajaran, maka lembaga pendidikan dapat meningkatkan mutu pendidikannya. Dengan demikian, maka pengelolaan administrasi mulai dari perencanaan, pelaksanaan, dan pengawasan menjadi salah satu yang cukup dominan dalam melakukan penilaian serta peningkatan mutu pendidikan pada sebuah lembaga pendidikan.

\section{Daftar Pustaka}

Anonim, Pengelolaan Pendidikan, (Jakarta: Rineka Cipta, 2005)

\footnotetext{
${ }^{17}$ Purwanto, Administrasi Pendidikan, 28.

18 Tsauri, Administrasi dan Supervisi Pendidikan, 22.
} 
Aan Komariah, Visionary Leadership Menuju Sekolah Efektif, (Jakarta: Bumi Aksara, 2005)

Burhanuddin, Administrasi Pendidikan, (Bandung:Pustaka Setia, 2005)

Direktorat Jenderal Kelembagaan Agama Islam, Desain Pengembangan Madrasah, (Jakarta : Departemen Agama RI, 2004)

Depdikbud, Pedoman Supervisi, (Jakarta: Depdikbud, 2010)

Hasal Alwi, Kamus Besar Bahasa Indonesia, (Jakarta: Balai Pustaka, 2005)

Nurhadi, Administrasi Pendidikan, (Jakarta: Balai Pustaka, 2009)

Purwanto, Ngalim. Administrasi Pendidikan dan supervisi pendidikan, (Bandung: Remaja Rosda Karyta, 2007)

Sardiman, Interaksi dan Motivasi Belajar Mengajar, (Jakarta: Raja Grafindo, 2003)

Soetjipto dan Kosasi, Raflis, Profesi Keguruan, (Jakarta: Rineka Cipta, 2005)

Soetopo, Hendyat, Pembinaan dan Pengembangan Kurikulum Sebagai Subtansi Problem Administrasi Pendidikan, (Jakarta: Bumi Aksara, 1993)

Sutjipto dan Basori Mukti, Administrasi Pendidikan, (Jakarta: Depdikbud Dirjen Dikti, 1993)

Tsauri, Sofyan, Administrasi dan Supervisi Pendidikan. (Jember: Center for Society Studies, 2007) 